\title{
New Method to Measure Abrasion of Motorcyclist Protective Clothing
}

Nova metoda merjenja drgnjenja zaščitnih oblačil za motoriste

\author{
Short Scientific Article/Kratki znanstveni prispevek \\ Received/Prispelo 03-2018 • Accepted/Sprejeto 06-2018
}

\begin{abstract}
Motorcyclists often suffer severe injuries in accidents, especially at high temperatures when wearing thinner garments. Producing adequate protective clothing for them is therefore of great importance. Nevertheless, typical test procedures for protective clothing often cannot represent a real accident situation and scientific literature about this topic is scarce. Thus, in our project, a simple, inexpensive and realistic test setup was created. Experiments revealed significant differences between typical motorcycle protective clothing materials under examination, indicating that especially those produced from man-made fibres can lead to burns and worse injuries of motorcyclists, while some relatively inexpensive materials showed surprisingly high abrasion resistance. More importantly, the test results partly differ from those performed with one of the standard testing devices, implying the importance of future tests to compare different testing procedures with the results of real accidents.

Keywords: protective clothing, motorcyclist, abrasion resistance, concrete, asphalt
\end{abstract}

\section{Povzetek}

Motoristi pogosto utrpijo hude poškodbe v nesrečah, še posebej pri visokih temperaturah, ko nosijo tanjša oblačila. Zato so ustrezna zaščitna oblačila zanje izjemno pomembna. Tipični postopki za preiskušanje zaščitnih oblačil pa pogosto ne odražajo realnih pogojev nesreče. Prav tako obstaja zelo malo znanstvene literature o tej temi. Vnedavnem projektu je bila zato izdelana enostavna, poceni in realistična metoda, s katero so bile ugotovljene znatne razlike med tipičnimi proučevanimi materiali za zaščitna oblačila motoristov. Te kažejo na to, da zlasti materiali iz kemičnih vlaken lahko povzročijo opekline in poslabšajo poškodbe motoristov, medtem ko so se nekateri relativno poceni materiali pokazali presenetljivo visoko odpornost proti obrabi. Še pomembnejšeje, da rezultati nedavnih testov deloma odstopajo od tistih, ki jih izvajajo na eni od standardnih preskuševalnih naprav, kar kaže na potrebo po nadaljnih primerjavah različnih metod z rezultati realnih nesreč.

Ključne besede: zaščitna oblačila, motorist, odpornost proti obrabi, beton, asfalt

\section{Introduction}

Motorcyclists are disproportionately highly involved in accidents with severe injuries, since only their garments and their protective equipment - footwear, gloves and helmet - can protect them, opposite to the deformable zone of a car. Together with pedestrians and cyclists, approx. half of global fatal

Corresponding author/Korespondenčna avtorica:

Prof. Dr. Dr. Andrea Ehrmann

E-mail: andrea.ehrmann@fh-bielefeld.de traffic accidents apply to these unprotected road users [1]. In most cases, injuries of motorcyclists who wear helmets are related to soft tissue [2], while in the countries where helmets are not mandatory, head injuries have a much higher impact [3].

Impact protectors for motorcyclists have been examined in several studies [4-6]. The influence of protective clothing, i.e. the outer shell of garments,

Tekstilec, 2018, 61(3), 152-161

DOI: 10.14502/Tekstilec2018.61.152-161 
on soft tissue injuries and other severe injuries was investigated as well, finding that protective clothing helped reducing the risk and severity of injuries $[7,8]$. On the other hand, a large proportion of clothing failed in real accidents [7].

Therefore, the European standard EN 13595 "Protective clothing for professional motorcycle riders Jackets, trousers and one piece or divided suits" was established in 2002. Recent publications have discussed the zone approach in this standard, defining different levels of protection and different test methods for the four zones, finding that this concept is generally suitable to define the necessary degree of protection in different garment areas $[9,10]$.

In one study, the relation between the protective level in EN 13595-1 "Part 1: General requirements" and the protection in a real accident was examined, finding that the standard allows for approximate estimating the real degree of protection, but also shows that more than a half of garments did not even meet the minimum requirements [1]. This shows clearly the necessity to make more reliable tests available for the industry along with the whole production chain of protective clothing for motorcyclists.

The testing of materials according to EN 13595-2 "Part 2: Test method for determination of impact abrasion resistance" was, depending on the protection zone, performed using the Taber ${ }^{\circledR}$ Abraser. This instrument was developed for accelerated wear testing. It produces a rub-wear action by rotating a test specimen in a horizontal plane against the sliding rotations of two abrading wheels rotating in vertical planes [11]. The pressure of the rubbing wheels on the sample is usually $10 \mathrm{~N}$. Such a combination of rolling friction and dynamic friction under low pressure, however, may not be an ideal representation of the situation in a motorcyclist's accident. Nevertheless, the number of rotations until a hole occurs is often depicted in motorcyclists' protective wear. Table 1 gives an overview of the range of Taber ${ }^{\ominus}$ Abraser breakthrough values, as it could be found in the literature.

Apart from this test, in EN 13595-2, the seam burst strength is investigated using a burst tester and the impact cut is tested by measuring the maximum penetration of a defined blade through a fixed test specimen.

Another approach is suggested in [12], using a belt abrader instead of the rub-wear action used in EN 13595-2. Here, a static force of $49 \mathrm{~N}$ (consistent with the pressure of $25 \mathrm{kPa}$ ) is used. The sample falls from two different heights - simulating the first impact and the sliding afterwards - onto a grid belt moving with $8 \mathrm{~m} / \mathrm{s}$, i.e. $28.8 \mathrm{~km} / \mathrm{h}$, resulting in 0.2-10 s abrasion times.

Other test equipment, e.g. Martindale or linear abrasion testers, use low velocities, normally without the possibility of increasing the value.

Consequently, in this research, a fast, simple and inexpensive test method was evaluated with respect to leather and man-made materials in protective garments for motorcyclists, which tries to combine the advantages of the methods described above.

Table 1: Taber ${ }^{\circledR}$ Abraser breakthrough values from the literature

\begin{tabular}{|l|c|c|}
\hline \multicolumn{1}{|c|}{ Material } & Breakthrough [abr. cycles] & Reference \\
\hline SuperFabric $^{\oplus}$ (woven) & $>5000$ & {$[13]$} \\
\hline Cordura (woven) & 2000 & {$[13]$} \\
\hline Automotive leather with polyurethane/acrylic coating & 3000 & {$[14]$} \\
\hline PES with epoxy resin plates (woven) & 1250 & {$[15]$} \\
\hline Cow leather & 185 & {$[16]$} \\
\hline Kangaroo leather & 350 & {$[16]$} \\
\hline Goat leather & 750 & {$[16]$} \\
\hline Stingray (fish) leather & $>1000$ & {$[16]$} \\
\hline Kevlar (woven) & 571 & {$[17]$} \\
\hline Kevlar/Nomex/PBO (woven) & 933 & {$[18]$} \\
\hline Kevlar/Nomex (woven) & 350 & {$[18]$} \\
\hline Kevlar/PBI (woven) & 367 & {$[18]$} \\
\hline
\end{tabular}




\section{Materials and methods}

The following samples, presented in Table 2, were made available for investigations by the company Held Biker Fashion (Held GmbH, Burgber-Erzflöße, Germany).

A micrometre caliper was used to measure the sample thickness at three positions along the radius between the middle and the edge of the abraded part before and after the testing. Usual textile thickness measurement instruments have significantly larger measurement areas and are thus not suitable for measuring the varying thicknesses in these experiments. The values given here are thus underestimated in comparison with those measured with a textile thickness measurement instrument, especially in the case of the highly compressible knitted fabric. Areal weight was measured by cutting the samples into the size of $10 \mathrm{~cm}^{2}$ (due to the sizes of available samples larger areas were not possible) and measuring the masses on an analytical balance (VWR).

The last two fabrics are not suitable for protective purposes and are thus added for comparison.

SuperFabric ${ }^{\oplus}$ has a surface structure similar to skate leather. Leather materials were soft and bendable, while the man-made materials were harder and stiffer. Since only small samples were provided, not enough material was available for cross-checking using the Taber ${ }^{\oplus}$ Abraser or a belt abrader. Instead, the few test results available in scientific literature, apart from the producers' own websites, are given here for comparison.

As an easy and well-available testing method, combining the pure dynamic friction of the belt abrader with the circular movement of the Taber Abraser, a pillar drilling machine was used (Figure 1). The sample holder was taken from the Martindale abrasion tester (according to DIN EN ISO 12947), an instrument which is available in most textile institutes, using the standard setup with one standard Martindale spacer layer. The force between the sample in the sample holder and the abrading object below is controlled using the scales below the abrasion stone. Since radial velocities increase from the middle to the border of the abraded area, this method enables creating a velocity profile along the radius of each sample. The abraded sample area has the diameter of $28.65 \mathrm{~mm}$. Using the force of $100 \mathrm{~N}$, this results in the pressure of $95.7 \mathrm{kN} / \mathrm{m}^{2}=95.7 \mathrm{kPa}$. This value is about $4 \times$ the value used in the belt abrader test, simulating the sliding of a motorcyclist of $80 \mathrm{~kg}$ in weight on a circular area with the diameter of $82 \mathrm{~mm}$, which is a typical order of magnitude of one knee, elbow or hand.

While overestimating this value in the test described here, the maximum frequency of the available pillar drilling machine resulted in the maximum velocity of $2.9 \mathrm{~m} / \mathrm{s}=10.4 \mathrm{~km} / \mathrm{h}$, which is clearly underestimated and even smaller than the value of a belt abrader. Nevertheless, this value - as well as the

Table 2: Samples under investigation and available information about them

\begin{tabular}{|l|l|c|c|}
\hline \multicolumn{1}{|c|}{ Sample } & \multicolumn{1}{|c|}{ Fabric construction } & $\begin{array}{c}\text { Thickness } \\
{[\mathrm{mm}]}\end{array}$ & $\begin{array}{c}\text { Areal weight } \\
{\left[\mathrm{g} / \mathrm{m}^{2}\right]}\end{array}$ \\
\hline Skate leather & Leather & 1.83 & 2450 \\
\hline Kangaroo leather for gloves & Leather & 0.67 & 523 \\
\hline Kangaroo leather for other garments & Leather & 1.43 & 971 \\
\hline Vegetable tanned calf leather & Leather & 0.89 & 712 \\
\hline Kevlar-ceramic & Woven fabric + coating & 0.55 & 359 \\
\hline Carbon-Kevlar & Knitted fabric + coating & 0.71 & 374 \\
\hline Cordura D500 (polyamide) & Woven fabric & 0.40 & 278 \\
\hline Gore material with membrane & $\begin{array}{l}\text { Woven fabric outside + } \\
\text { membrane + knitted fabric inside }\end{array}$ & 0.66 & 380 \\
\hline $\begin{array}{l}\text { SuperFabric } \\
\text { resin) }\end{array}$ & Woven fabric + partial coating & 0.99 & 737 \\
\hline Knitted fabric version 3a (polyester) & Knitted fabric & 1.43 & 792 \\
\hline Denim & Woven fabric & 0.74 & 421 \\
\hline
\end{tabular}


pressure on the sample - can be tailored to testing conditions closer to reality.

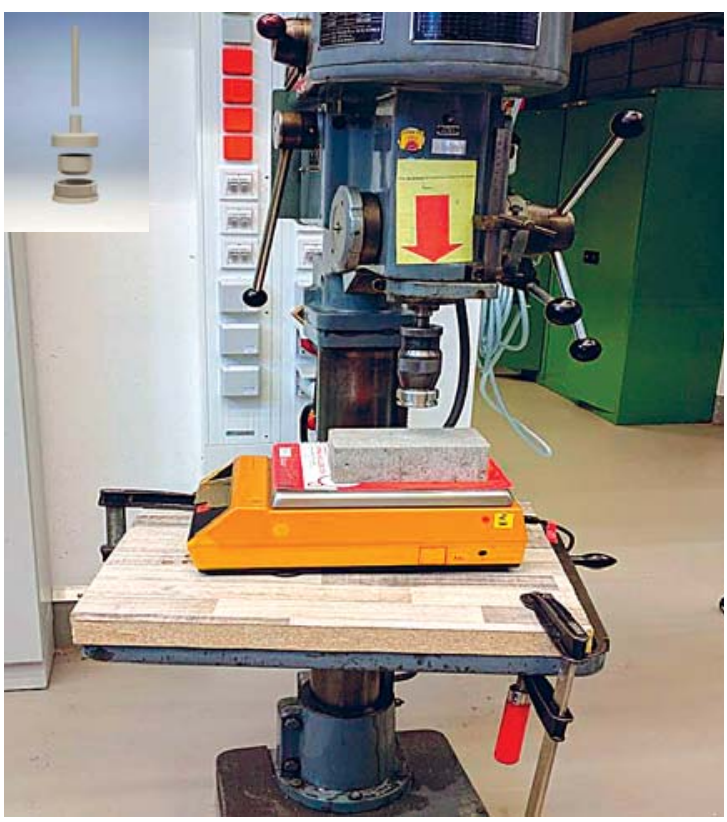

Figure 1: Pillar drilling machine used for tests reported here (left panel) and sketch of sample holder taken from Martindale abrasion tester (right panel)

All abrasion tests were performed during $30 \mathrm{~s}$, using 3 specimens of each sample.

Opposite to all other testing methods described above as well as the Martindale or linear abrader, the use of a pillar drilling machine allows for using real concrete, asphalt or similar materials as abrading objects. In our research, we used a paving stone with a fine surface structure, similar to typical asphalt in Germany and other European countries. For the second test, a lawn edging stone was used with a courser surface structure.

For optical examination of samples, a digital microscope VHX-600D by Keyence (nominal magnification $50 \times$ ) and a camera were used.

\section{Results and discussion}

The samples were evaluated before and after the abrasion tests optically and by measuring the thickness. The first idea to also take into account the masses before and after the tests was excluded due to the following reasons: firstly, it was not clear how to handle nearly completely torn off areas, whether they had to be cut away before weighing or not; secondly, since the outer area - which was not influenced by the test - would keep its mass, it would be hard to interpret the results by calculating a relative mass loss - even a completely abraded sample would still have the border area left so that the values like $100 \%$ loss of mass would not be possible; finally, during the experiments, it became evident that some of the man-made materials were molten together with the Martindale spacer layers on the sample holder after the tests, leading to even higher masses and thus distorting the results.

The results of thickness measurements before and after both abrasion tests are depicted in Figure 2. Comparing all leathers, skate leather had the highest remaining thickness after the tests, apparently giving the highest security, due to its large original thickness. Nevertheless, most other leathers, including the softer and thinner calf leather and kangaroo leather for gloves, showed only small abrasive wear. Unexpectedly, in the thicker kangaroo leather for other garments, a hole was found for rubbing on a lawn edging stone, i.e. the material failed for the abrasion test.

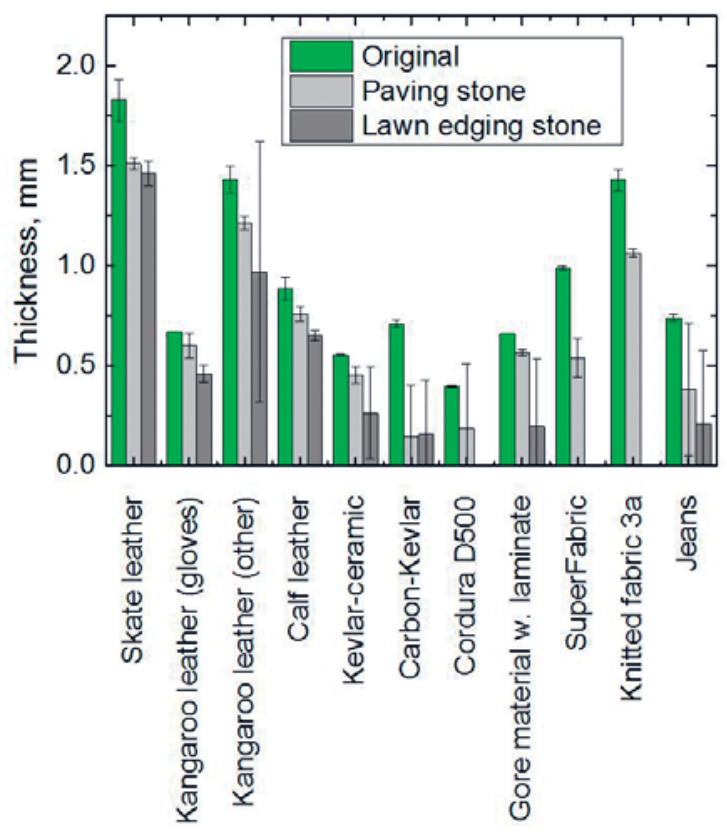

Figure 2: Thicknesses of test samples before and after abrasion tests

Kevlar-ceramic with its smaller original thickness protects against abrasion on a paving stone, but not on a lawn edging stone - here, a standard deviation significantly increased, meaning that the holes in 
the material cannot be excluded and were found during the test.

The situation was similar in carbon-Kevlar, Cordura, Gore material and SuperFabric ${ }^{\oplus}$. Here, in one or more cases, holes occurred during the tests on a lawn edging stone; for carbon-Kevlar and Cordura, even during the tests on a paving stone. This means that all synthetic materials failed the test on a rougher lawn edging stone, even at the low test velocity. Unexpectedly, carbon-Kevlar and Cordura, typical materials in motorcyclist protective clothing, failed even the test on the paving stone.

On the other hand, the knitted fabric 3a was not punctured during the abrasion test on a paving stone, but completely destroyed after the abrasion on a rougher lawn edging stone. The denim showed holes in both tests.
Interestingly, SuperFabric ${ }^{\circledR}$ gives the best results in the literature, followed by automotive leather with a special coating, Cordura, PES with epoxy resin plates (a similar idea as in SuperFabric ${ }^{\circledR}$ ), fish leather and Kevlar/Nomex/PBI. This is in direct contrast to the findings of our study, where the SuperFabric $^{\circ}$ and Cordura were completely destroyed during the abrasion on a lawn edging stone, while the simple calf leather and the skate (fish) leather showed the smallest losses, even when without any additional coating. Apparently, the test methods differ significantly in their results, making it necessary to perform a follow-up study using different test standards.

An optical examination of different materials before and after the tests revealed more information about the influence of abrasion on the samples. Table 3

Table 3: Leather samples before (left panels) and after abrasion tests (middle panels: abrasion on paving stone; right panels: abrasion on lawn edging stone)

\begin{tabular}{|l|l|l|l|}
\hline \multicolumn{1}{|c|}{ Fabrics } & Original & Paving stone & Lawn edg. stone \\
\hline Skate leather & & & \\
\hline & & & \\
\hline
\end{tabular}


depicts the images of the four leather surfaces before and after the abrasion tests.

While the skate leather showed strong abrasive wear of the nubs, the optical change of the thinner kangaroo leather was less eye-catching. On the thicker kangaroo leather, the original structure was lost as well. A small hole - interestingly near to the middle, i.e. at lower velocities - was clearly visible. The calf leather showed the lowest optical deviation from the original state after the abrasion tests.

Microscopic images of the same samples, taken with the nominal magnification of 50x, are depicted in Table 4.

Table 5 shows the results of the abrasion tests on man-made materials. In all materials, holes were visible at the abrasion against a lawn edge stone, for carbon-Kevlar and Cordura even at the abrasion against a paving stone.
In some cases, the fabrics were additionally stiffer after the tests, showing that parts of the material were molten and thus fused, partly also in connection with the Martindale spacer layer between the metal sample holder and the investigated sample itself.

The microscopic images of these samples are depicted in Table 6. Finally, the test results of softer fabrics, which are not suitable as protective clothing, are depicted in Table 7. While the dense knitted fabric with relatively low elongation and tight surface was not punctured by rubbing on a paving stone, the rougher surface of a lawn edge stone destroyed it. The denim was in both test setups destroyed.

Although denim, made from cotton, does not tend to melt and fuse together with objects around, it must be underlined that denim does not provide

Table 4: Microscopic images of leather samples before (left panels) and after abrasion tests (middle panels: abrasion on paving stone; right panels: abrasion on lawn edging stone); nominal magnification: $50 \times$

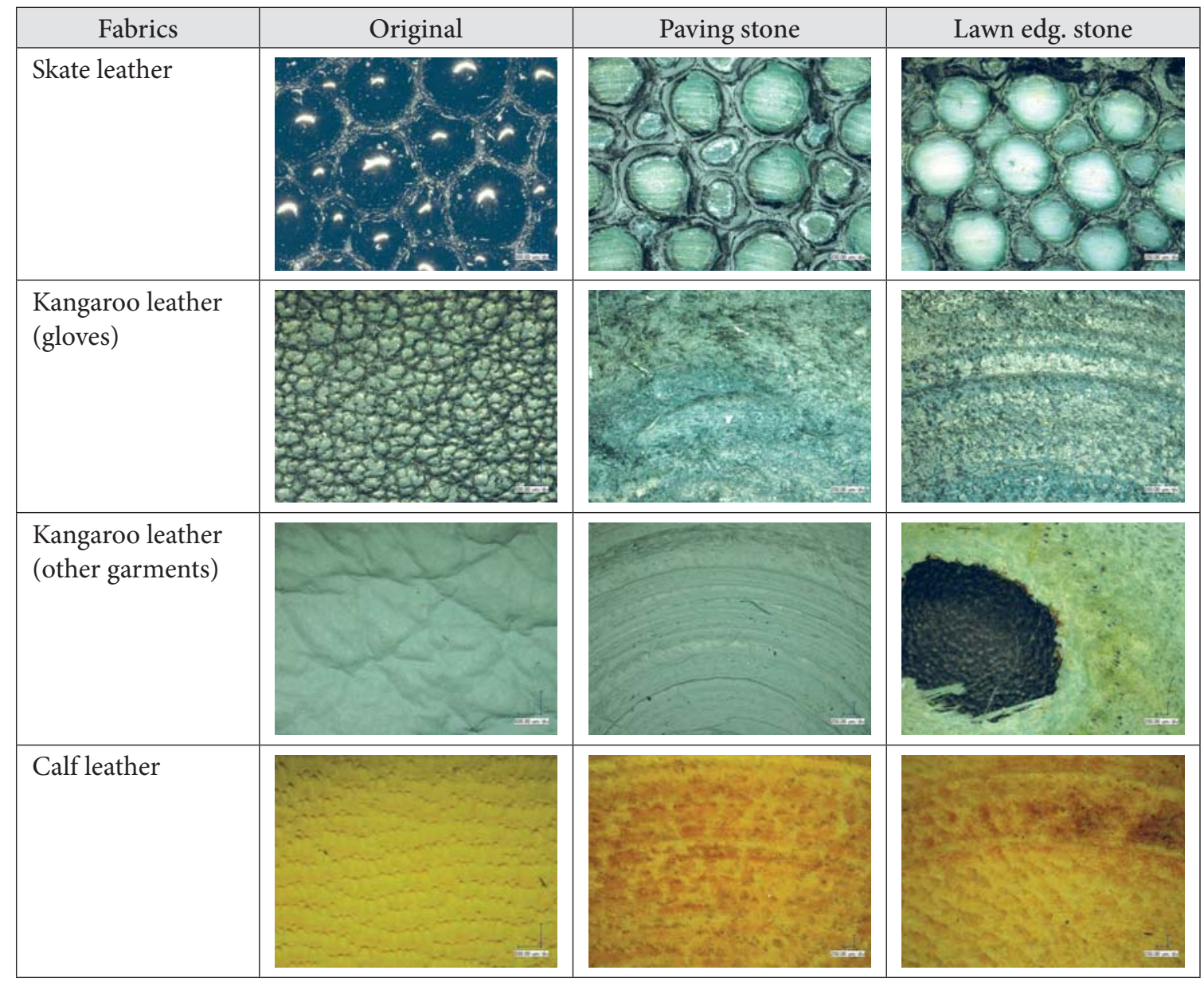


Table 5: Man-made samples before (left panels) and after abrasion tests (middle panels: abrasion on paving stone; right panels: abrasion on lawn edging stone)

\begin{tabular}{|l|c|c|c|}
\hline \multicolumn{1}{|c|}{ Fabrics } & Original & Paving stone & Lawn edg. stone \\
\hline Kevlar-ceramic & & & \\
\hline Carbon-Kevlar & & \\
\hline SuperFabric ${ }^{\circ}$ & & \\
\hline Gore material with laminate & & \\
\hline
\end{tabular}

any shelter, but is destroyed even in a less harsh test. The latter is also visible in the microscopic images in Table 8.

Unexpectedly, this holds true also for two of the wellknown and often used man-made materials, while the leather materials mostly showed a much higher reliability to withstand abrasion on rough ground. Especially the calf leather, being often used and relatively inexpensive, showed a good abrasion performance.
On the other hand, it must be underlined that the results of the test used here do not exactly reflect the real accident situation, in which mostly a linear movement occurs, similar to a belt abrader. Nevertheless, they indicate the importance of performing tests on motorcyclist protective clothing, ideally with a variety of different experimental procedures which are capable of simulating diverse kinds of abrasive wear in an accident. 
Table 6: Microscopic images of man-made samples before (left panels) and after abrasion tests (middle panels: abrasion on paving stone; right panels: abrasion on lawn edging stone); nominal magnification: 50×

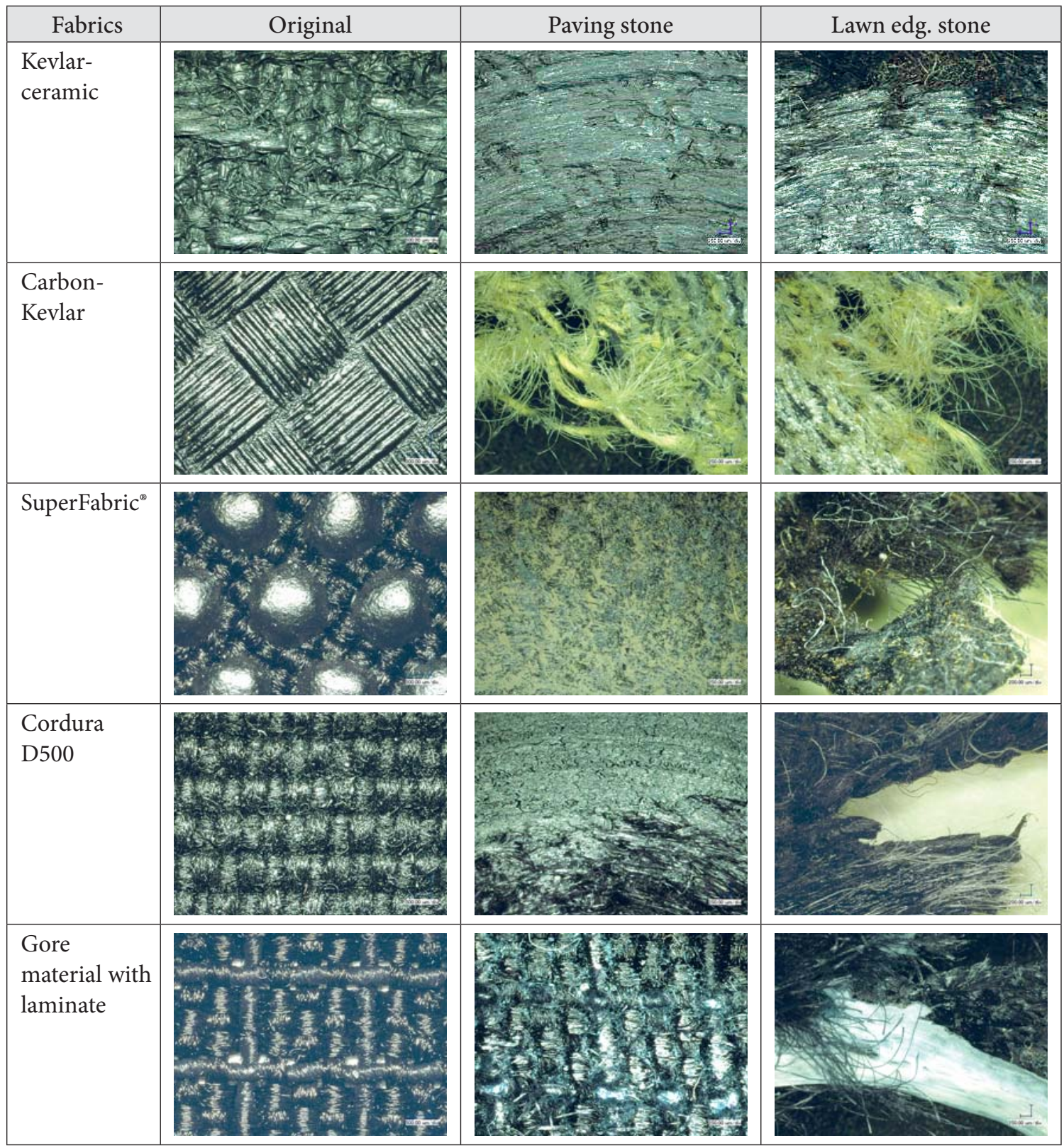


Table 7: Reference samples before (left panels) and after abrasion tests (middle panels: abrasion on paving stone; right panels: abrasion on lawn edging stone)

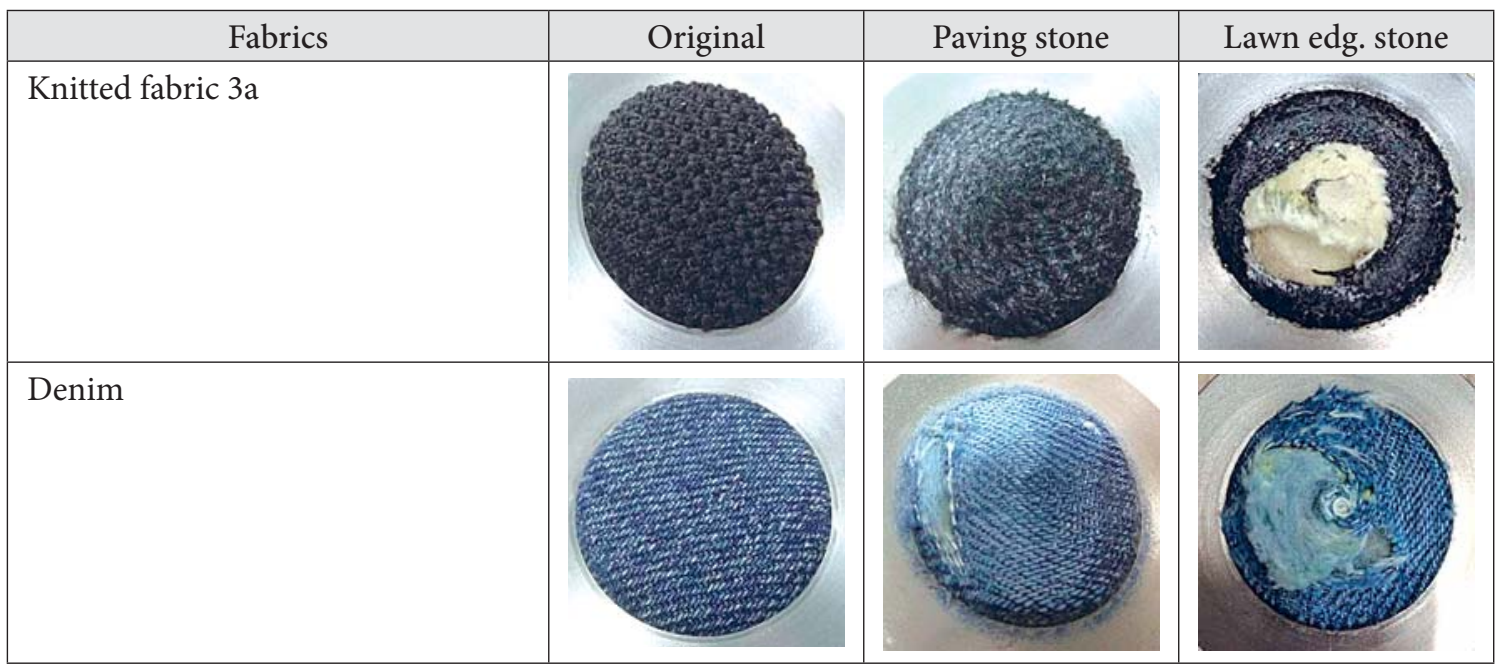

Table 8: Microscopic images of reference samples before (left panels) and after abrasion tests (middle panels: abrasion on paving stone; right panels: abrasion on lawn edging stone); nominal magnification: 50×

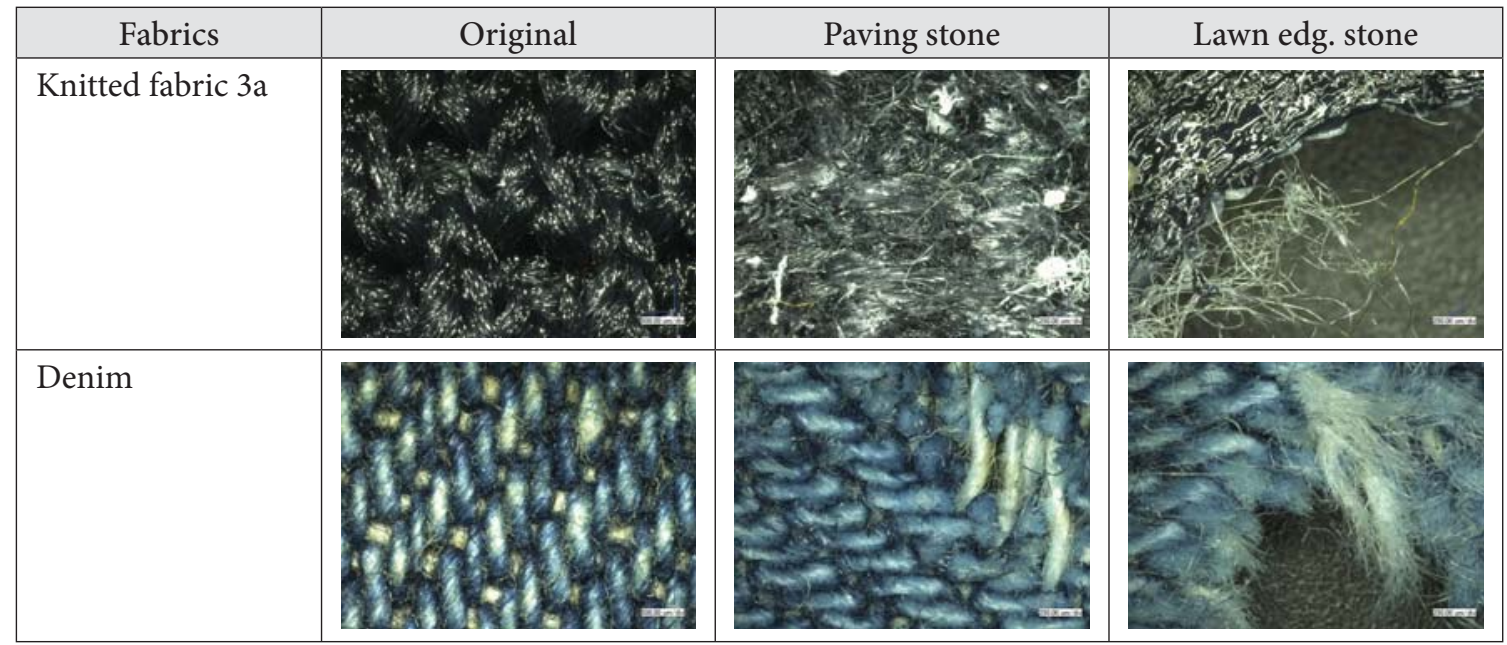

\section{Conclusion and outlook}

A new, simple test procedure for the motorcyclist protective wear against soft tissue injuries was developed and tested on 11 different samples. While the leather samples in most cases showed only low abrasion, all samples from man-made fibres were punctured by abrasion on rougher ground, some of them even by abrasion on a smoother stone. These results - which are contrary to those found in the literature from Taber ${ }^{\otimes}$ resistance tests - clearly indicate the importance of testing all abrasion protec- tion garments with a reliable method, ideally using more than one test stand to simulate different possible accident situations.

Additionally, expanding this study to other materials, using also less abrasive materials as abrasion partners, would support the understanding of different effects of diverse abrasion testers, such as the Martindale or linear abrasion tester.

\section{Acknowledgments}

The authors are grateful to Held Biker Fashion for providing all test samples. 


\section{References}

1. ARAUJO, Miguel, ILLANES, Eduardo, CHAPMAN, Evelina, RODRIGUES, Eugênia. Effectiveness of interventions to prevent motorcycle injuries: systematic review of the literature. International Journal of Injury Control and Safety Promotion, 2017, 24(3), 406-422, doi: 10.1080/ 17457300.2016.1224901.

2. MEREDITH, Lauren, HURREN, Christopher, CLARKE, Elizabeth, FITZHARRIS, Michael, BALDOCK, Matthew, DE ROME, Liz, OLIVIER, Jake, BROWN, Julie. Validation of the abrasion resistance test protocols and performance criteria of EN13595: The probability of soft tissue injury to motorcycle riders by abrasion resistance of their clothing. Journal of Safety Research, 2017, 61, 1-7, doi: 10.1016/j.jsr.2017.02.001.

3. FOUDA, El Yamani, YOUSSEF, Mohamed, EMILE, Samed H., ELFEKI, Hossam, THABET, Waleed, ABDALLAH, Emad, ELSHOBAKY, Ayman, TOMA, Mohamed S., KHAFAGY, Wael. Pattern of major injuries after motorcycle accidents in Egypt: The Mansoura Emergency Hospital experience. Trauma - England, 2017, 19(1), 39-45, doi: 10.1177/1460408616652924.

4. ALBANESE, Bianca, GIBSON, Tom, WHYTE, Tom, MEREDITH, Lauren, SAVINO, Giovanni, DE ROME, Liz, BALDOCK, Matthew, FITZHARRIS, Michael, BROWN, Julie. Energy attenuation performance of impact protection worn by motorcyclists in real-world crashes. Traffic Injury Prevention, 2017, 18(sup1), S116-S121, doi: 10.1080/15389588.2017.1311014.

5. EKMEJIAN, Rafael, SARRAMI, Pooria, NAYLOR, Justine M., HARRIS, Ian A. A systematic review on the effectiveness of back protectors for motorcyclists. Scandinavian Journal of Trauma Resuscitation Emergency Medicine, 2016, 24, 115, doi: 10.1186\%2Fs13049-016-0307-3.

6. GIUSTINI, Marco, CEDRI, Sabina, TALLON, Marco, ROAZZI, Paolo, FORMISANO, Rita, PITIDIS, Alessio. Use of back protector device on motorcycles and mopeds in Italy. International Journal of Epidemiology, 2014, 43(6), 1921-1928, doi: 10.1093/ije/dyu209.

7. DE ROME, Liz, IVERS, Rebecca, FITZHARRIS, Michael, DU, Wei, HAWORTH, Narelle, HERITIER, Stephane, RICHARDSON, Drew. Motorcycle protective clothing: Protection from injury or just the weather? Accident Analysis and
Prevention, 2011, 43(6), 1893-1900, doi: 10.1016/ j.aap.2011.04.027.

8. DE ROME, Liz, IVERS, Rebecca, FITZHARRIS, Michael, HAWORTH, Narelle, HERITIER, Stephane, RICHARDSON, Drew. Effectiveness of motorcycle protective clothing: Riders' health outcomes in the six months following a crash. Injury - International Journal of the Care of the Injured, 2012, 43, 2035-2045, doi: 10.1016/j. injury.2011.10.025.

9. MEREDITH, Lauren, BROWN, Julie, IVERS, Rebecca, DE ROME, Liz. Distribution and type of crash damage to motorcyclists' clothing: Validation of the zone approach in the European standard for motorcycle protective clothing, EN13595. Traffic Injury Prevention, 2014, 15(5), 501-507, doi: 10.1080/15389588.2013.838672.

10. DE ROME, Liz, MEREDITH, Lauren, IVERS, Rebecca, BROWN, Julie. Validation of the principles of injury risk zones for motorcycle protective clothing. Journal of Safety Research, 2014, 50, 83-87, doi: 10.1016/j.jsr.2014.04.003.

11. Taber Abraser [online]. Taber Industries [accessed 23.03.2018]. Available on World Wide Web: http://www.taberindustries.com/taberrotary-abraser.

12. WOODS, R. I. Belt abrader impact abrasion testing of leathers and fabrics used in motorcycle riders' clothing. In Performance of Protective Clothing: Fifth Volume ASTM STP. Edited by J. Johnson, S. Z. Mansdorf. Philadelphia : American Society for Testing and Materials, 1996, 1237, 57-69.

13. WILLIAMS, Ben S. Insulated containers for bottled water (ICB) - performance evaluation. Technical Report Natick/TR-17/013, 2017.

14. WINKLER, Herrmann. Natural Grain Leather. US Patent 7552605B2. 2009-06-30.

15. KIM, Young, JI, Hong. Abrasion and heat resistant fabrics. US Patent 20040192133 A1. 2004-09-30.

16. SKIRROW, Simon Jeremy. Goat Skin for Shoe and Apparel Manufacture. US Patent 20080271344 A1. 2008-11-06.

17. LUO, Jie, SUN, Yuyu. Acyclic N-Halamine coated Kevlar fabric materials: Preparation and Biocidal Functions. Industrial and Engineering Chemistry Research, 2008, 47(15), 5291-5297, doi: 10.1021/ie800021p.

18. CORNER, Christopher, JEWELL, Stan. Blended outer shell fabrics. US Patent 20060084337 A1. 2006-04-20. 